\title{
Assessment and analysis of road transport driver's behavior in terms of eco-driving
}

\author{
Sebastian Kilimni $k^{1,}{ }^{,}$, Lukasz Muślewski ${ }^{1}$ and Wojciech Kilimnik ${ }^{2}$ \\ ${ }^{1}$ University of Science and Technology, Facoulty of Mechanical Engineering, A I. prof. S. Kaliskiego \\ 7 85-789 Bydgoszcz, Poland \\ ${ }^{2}$ BWS D oradztwo i szkolenia, Tulipanowa 20 Street, 89-200 Zamość, Polska
}

\begin{abstract}
Eco driving courses are one of the methods to gain cost savings in transport companies. Road transport drivers equipped with appropriate knowledge of Eco- driving and defensive driving can reduce the costs of fuel consumption even by one third as compared to those involved in their previous driving style. This is the knowledge of a vehicle operation and ability to use driving techniques that leads to fuel consumption reduction. $B$ ased on the conducted tests, an analysis of behavior change of drivers who use Eco- driving in road transport systems has been performed. A comparison of the number of drivers' reactions to road situations allows to determine percentage change in their behavior which leads to fuel-efficient and ecological driving.
\end{abstract}

\section{Introduction}

Road transport provides the possibility of direct delivery of passengers or load to the destination which makes it one of the major transport forms. Nowadays, most of transport processes are carried out by vehicles equipped with combustion engines and emission of exhaust gases containing harmful substances are the side effect of their operation. To reduce the amount of pollution getting to the atmosphere, car manufacturers use modern technological solutions [1-7].

The main goal of engineers who are involved in engine construction is to improve exhaust gas filtration and reduce fuel consumption. The style of driving is an important factor that contributes to fuel consumption of transport means. Improving the driver's driving skills is very important not only for road traffic safety but also for fuel consumption and wear of the vehicle elements which in turn translates into harmful pollution reduction [8-18]. The goal of the study is to analyze and assess a change in the behavior of drivers who use Eco- driving in road transport systems. The results include data from accomplishing transport tasks prior to and after an Eco- driving course. An analysis of the results has been performed to find out how and to what degree the driving style changes when appropriate driving techniques are utilized by drivers.

\section{Methodology of Eco-driving training and description of measurable parameters}

In the first stage, courses in Eco-driving and defensive driving involve providing a test vehicle and auxiliary materials.

Conditions that need to be fulfilled include:

- preparing and securing an appropriate load similar to the real load to be carried by the vehicle,

- fuel tanks in the training vehicle need to be full,

* Corresponding address: sebastian.kilimnik@gmail.com 
- the vehicle must be serviced on a daily basis including the content of maintenance fluids, lights, control lights and tire pressure,

- verification of the driver's documents, preparation of a driver cards and/or a tachograph,

- adjustment of a seat for the trainer as well as auxiliary means such as clicker, stopper, note book, calculator, ballpens or training sheets.

The second stage involves checking the driver's skills prior to the course. According to or this purpose the driver accompanied by the trainer covers a test route consistently with his/her driving technique. In this case the trainer is supposed to observe and record inappropriate driving reactions of the driver to be later discussed. The next stage is the driver's participation in a theoretical lecture on the subject of:

- physical forces that affect the vehicle during driving including:

o rolling resistance,

- aerodynamic resistance,

- motion resistance down a hill,

- correct daily service of a vehicle and its inspection before driving,

- appropriate route planning,

- adequate reaction to road traffic reports,

- techniques of Eco- driving and defensive driving.

Theoretical knowledge allows to understand the rules which affect fuel consumption and in a safe and defensive way $[1,7,11,19,20]$.

The next part of the training course involves the trainer's demonstrative ride during which the course participants are provided with practical guidelines concerning a motor vehicle driving.

At the of the practical part of the course, each participant has a ride in compliance with Eco driving rules. The data from each ride is recorded and stored by telemetric devices fixed in the vehicle. The device is connected by means of a CAN rail to enable recording drivers' behavior. General parameters to be provided are [8]:

- measurement time,

- measuring length,

- average speed,

- fuel consumption on measuring,

- mean fuel consumption in liters per $100 \mathrm{~km}$,

- average exhaust fume emission $\mathrm{CO}_{2}$.

Parameters to be used for the description of a driver's behavior [11]:

- average position of accelerator pedal use,

- maximal position of accelerator pedal use,

- the vehicle time in operation without using accelerator pedal (rolling),

- time of the brake pedal use,

- total distance without using accelerator pedal,

- total distance with using the brake pedal,

- repeatability of braking,

- repeatability of stopping,

- time of a stop,

- repeatability of gear shifting,

- repeatability of gear upshifting,

- total amount of engine revolutions,

- average rotational engine speed.

Table 1, shows an exemplary data sheet to be red by means of telemetric devices obtained from the training. 
Table 1. Exemplary data sheet obtained from the training.

\begin{tabular}{|c|c|c|c|c|c|}
\hline \multicolumn{5}{|c|}{ Driver's name, surname } & Date \\
\hline \multicolumn{5}{|c|}{ Driver 1} & 09.07.2018 \\
\hline \multicolumn{6}{|c|}{ MEASUREMENT RESULTS } \\
\hline & Unit & Route 1 & Route 2 & Difference & $\begin{array}{c}\text { Difference } \\
{[\%]}\end{array}$ \\
\hline M easurement time & $\mathrm{mm}: \mathrm{ss}$ & 01:13:20 & $01: 10: 52$ & $00: 02: 28$ & $-3.36 \%$ \\
\hline M easuring length & $\mathrm{km}$ & 71.51 & 71.43 & -0.08 & $-0.11 \%$ \\
\hline A verage speed & $\mathrm{km} / \mathrm{h}$ & 58.51 & 60.48 & 1.97 & $3.36 \%$ \\
\hline $\begin{array}{l}\text { Fuel consumption during } \\
\text { stopping }\end{array}$ & I & 0.00 & 0.00 & 0.00 & $0.00 \%$ \\
\hline $\begin{array}{l}\text { Fuel consumption during } \\
\text { driving }\end{array}$ & I & 16.74 & 14.97 & -1.77 & $-10.60 \%$ \\
\hline Total fuel consumption & I & 16.74 & 14.97 & -1.77 & $-10.60 \%$ \\
\hline M ean fuel consumption & I/100km & 23.41 & 20.96 & -2.46 & $-10.50 \%$ \\
\hline $\begin{array}{l}\text { M ean emission of exhaust } \\
\text { CO2 }\end{array}$ & $\mathrm{kg} / 100 \mathrm{~km}$ & 62.28 & 55.74 & -6.54 & $-10.50 \%$ \\
\hline $\begin{array}{l}\text { A verage position of accelerator } \\
\text { pedal use }\end{array}$ & $\%$ & $32.96 \%$ & $30.22 \%$ & $-2.74 \%$ & $-8.32 \%$ \\
\hline $\begin{array}{l}\text { M aximal position of } \\
\text { accelerator pedal use }\end{array}$ & $\%$ & $100.00 \%$ & $99.20 \%$ & $-0.80 \%$ & $-0.80 \%$ \\
\hline $\begin{array}{l}\text { Time of the vehicle in } \\
\text { operation without using } \\
\text { accelerator pedal }\end{array}$ & $\mathrm{mm}: \mathrm{ss}$ & $00: 14: 11$ & $00: 24: 00$ & 00:09:49 & $69.17 \%$ \\
\hline Time of using brakes & $\mathrm{mm}: \mathrm{ss}$ & $00: 08: 28$ & $00: 01: 12$ & $00: 07: 16$ & $-85.79 \%$ \\
\hline $\begin{array}{l}\text { Total distance without using } \\
\text { accelerator pedal }\end{array}$ & $\mathrm{km}$ & 13.31 & 24.67 & 11.36 & $85.33 \%$ \\
\hline $\begin{array}{l}\text { Total distance with using } \\
\text { brakes }\end{array}$ & $\mathrm{km}$ & 6.62 & 0.60 & -6.02 & $-90.94 \%$ \\
\hline Repeatability of braking & & 87 & 13 & -74 & $-84.48 \%$ \\
\hline Repeatability of stopping & & 2 & 0 & -2 & $-100.00 \%$ \\
\hline Time of stop & $\mathrm{mm}: \mathrm{ss}$ & $00: 02: 02$ & 00:00:00 & $00: 02: 02$ & $-100.00 \%$ \\
\hline Repeatability of gear shifting & & 118 & 148 & 30 & $25.42 \%$ \\
\hline Repeatability of upshifting & & 66 & 87 & 21 & $31.81 \%$ \\
\hline $\begin{array}{l}\text { Total repeatabilty of engine } \\
\text { revolutions }\end{array}$ & & 92267 & 74197 & -18070 & $-19.58 \%$ \\
\hline $\begin{array}{l}\text { A verage engine rotational } \\
\text { speed }\end{array}$ & $\mathrm{Rev} / \mathrm{min}$ & 1258 & 1047 & -211 & $-16.79 \%$ \\
\hline
\end{tabular}

The last part of the training course involves comparing parameters from the drivers' first ride with their ride after the training. Then, a participant gets familiar with the course results and the trainer can highlight and discuss the mistakes and share his/her additional comments. Below, in the chart (figure 1), there is an exemplary reading which describes the distance covered with the use of a particular gear during the first and the second ride after the training. Such data provides the basis for the trainer to determine whether the right technique was used by the driver. 


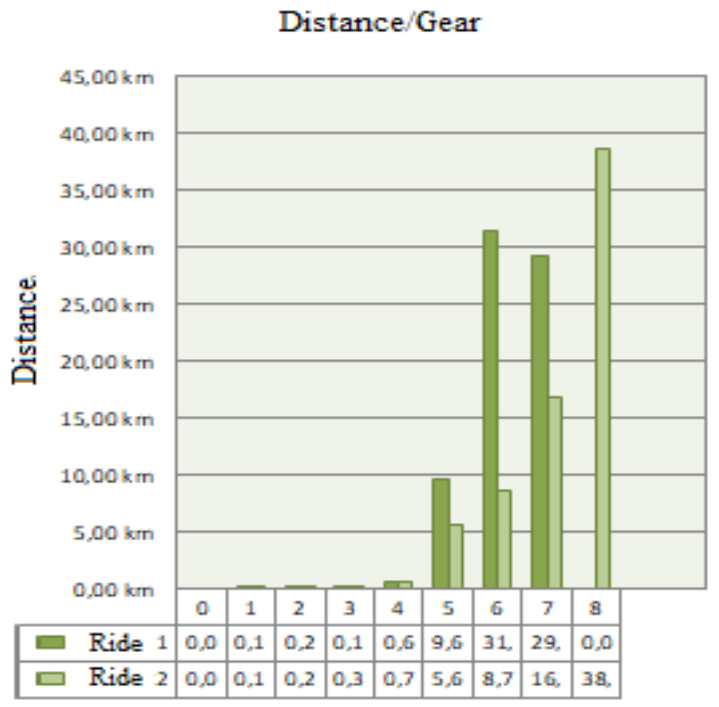

Fig. 1. Distance in relations to a given gear.

\section{Analysis of the study results}

The tests were conducted for a training group of thirty drivers. The mean length of a test route was seventy two and a half kilometers. The vehicle used for the training was a Mercedes-Benz Actors 1845 truck tractor with a semitrailer. Table 1 shows one of the study results. All data was transferred on the Excel sheet which allowed to calculate the mean values. One of the major factors indicating improvement in the driving quality is fuel consumption reduction. The mean value of fuel consumption during the rides prior to and after the course are presented in table 2 .

Table 2. Mean values of the vehicle fuel consumption during the course in Eco driving training.

\begin{tabular}{|c|c|c|}
\hline $\begin{array}{c}\text { Test ride } \\
\text { Mean value in } 1 \text { per } 100 \mathrm{~km}\end{array}$ & $\begin{array}{c}\text { Post course ride } \\
\text { Mean value in } 1 \text { per } 100 \mathrm{~km}\end{array}$ & $\begin{array}{c}\text { Mean saving in } 1 \text { per } \\
100 \mathrm{~km}\end{array}$ \\
\hline 20.33 & 17.86 & 2.47 \\
\hline
\end{tabular}

The elements of drivers' behavior which caused fuel consumption decrease were, among others, reduction in time of using the brake pedal and extension of time without using the accelerator pedal. Use of a brake in the first ride consistently with the driver's habits was seven minutes and thirty three seconds on the average which translated into a distance of five kilometers and four hundred meters. The ride after finishing the course showed reduction in the use of brake down to two minutes and twenty six seconds, whereas the distance covered with the use of a brake was one kilometer and two hundred seventy meters. When calculated into percentage value, the time of braking was reduced by $67.8 \%$ and the distance was reduced by $76.5 \%$.

The behavior characteristic of Eco- driving is driving without using the accelerator pedal. In the case of test rides the mean time value of the vehicle's rolling was thirteen minutes and six seconds which calculated for distance was twelve kilometers and eight hundred eighty meters, on the average. Based on the analysis of the data from the vehicle's rolling read after the course, a mean result equal to nineteen minutes and two seconds was reported, and the distance was calculated to be eighteen kilometers and five hundred forty meters. Percentage increase for the rolling time was $45.2 \%$ and for distance $44 \%$, respectively. The obtained results are depicted in figures 2 and 3. 
Change in the use of the accelerator and brake pedal measured in a time unit [mm:ss]

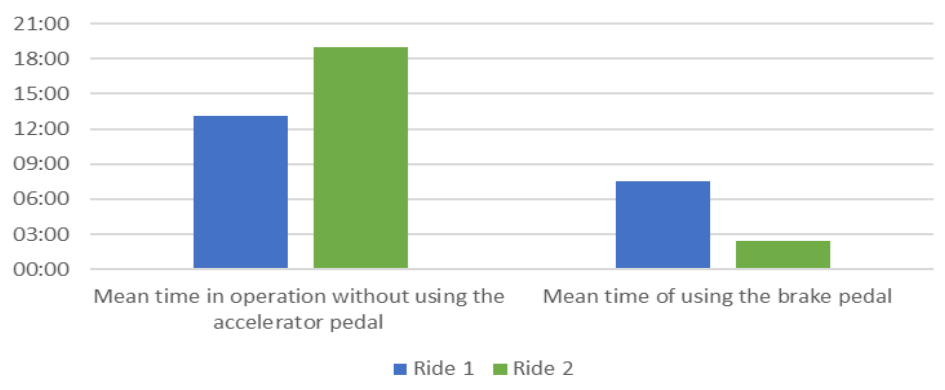

Fig. 2 Changes in the accel erator and brake pedal use measured in a time unit.

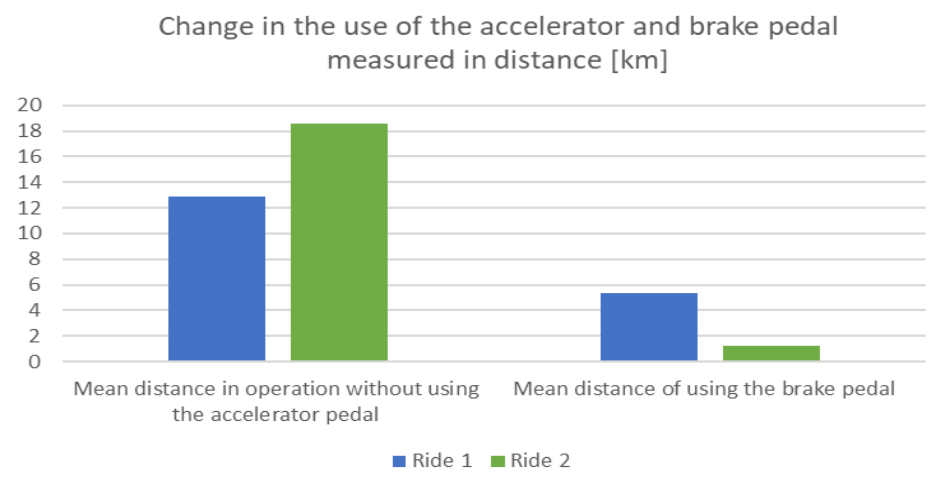

Fig. 3. Change in the gas pedal and brake use in terms of distance.

The obtained data made it possible to determine the driver' behavior significant for his/her style of driving. To reach economic style of driving a driver needs to reduce the number of stops in a safe manner. The mean value of this parameter during the test ride was five. After finishing the course drivers reduced stops to app. two. It means that Eco-driving allows to reduce stops by even $60 \%$. The next behavior associated with Eco driving is repeatability of braking and gear changing. The test ride included eighty eight uses of the brake and gear changes. The post course ride revealed reduction of the intensity of braking reducing the number of brake use to thirty five and gear shifts to eighty two. These results are presented in the chart of figure 4.

Change in repeatability of braking and gear shifts

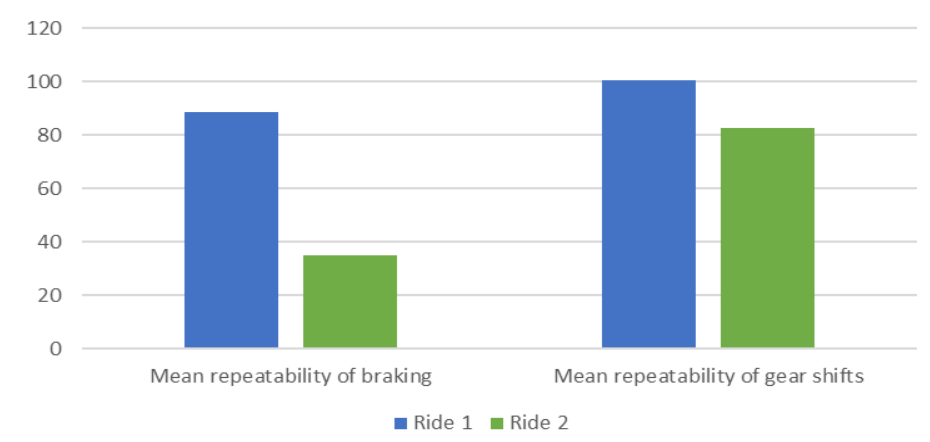

Fig. 4. Change in repeatability of braking and gear shifts. 
The parameter that has also changed is the engine rotational speed. During the test ride it was $1213 \mathrm{rev} . / \mathrm{min}$ for the first ride, whereas it was reduced down to $1132 \mathrm{rev} . / \mathrm{min}$ during training rides. It means that the average rotational speed decreased by $6.7 \%$. The overall results obtained from the study in $\%$ are shown in the below table.

Table 3. Percentage change in driving parameters as compared to the test ride.

\begin{tabular}{|l|c|}
\hline Parameter & $\begin{array}{c}\text { Change in relations to } \\
\text { the test ride }\end{array}$ \\
\hline $\begin{array}{l}\text { Mean time of a vehicle in motion without using the accelerator } \\
\text { pedal }\end{array}$ & $45.2 \%$ \\
\hline Mean time of brake using & $-67.8 \%$ \\
\hline Mean total distance without using the accelerator pedal & $44.0 \%$ \\
\hline Mean total distance with brake using & $-76.5 \%$ \\
\hline Mean repeatability of braking & $-60.4 \%$ \\
\hline Mean repeatability of gear shifting & $-18.0 \%$ \\
\hline Mean repeatibility of stopping & $-60.0 \%$ \\
\hline Mean engine rotational speed & $-6.7 \%$ \\
\hline
\end{tabular}

\section{Conclusions}

Based on the study results, it can be said that each of the course participants generated fuel savings which for the studied group of drivers was $12.15 \%$ on the average. Quantitative limitation of fuel consumption allows to gain economic profits and has a direct impact on environment harmful substance emission reduction.

The skills acquired during the course included an ability of defensive driving, which substantially contributed to time and distance reduction without the necessity to use the brake pedal. It also decreased the number of brake use by $60 \%$ as well as the vehicle stopping.

Utilization of Eco-driving techniques contributed to enhancement of the truck movement without its acceleration. The mean time of such a movement increased by $45.2 \%$, and the travelled distance by $44 \%$. Appropriate operation of the gear box contributed to reduction in the number of gear shifts by $18 \%$, whereas the average rotational speed of the engine was reduced by $6.7 \%$.

In conclusion it can be said that Eco driving training significantly changes the driver's behavior. Driving a car according to appropriate techniques is more predictable and the acquired knowledge allows to change the habits directly connected with operation of the accelerator brake pedals and the gear box.

\section{References}

1. S. Kilimnik, A. M azurkiewicz, K. M igawa, Ekonomiczne aspekty stosowania Ekojazdy w systemach transportu drogowego, Postępy w Inżynierii M echanicznej 12(6)/2018, 31-39, (2019)

2. M. M arkiewicz, Ł. Muślewski, The Impact Of Powering An Engine With Fuels From Renewable Energy Sources Including Its Software Modification On A Drive Unit Performance Parameters (Sustainability, V ol. 11, 2019).

3. M. Markiewicz, Ł. Muślewski, M. Pająk, Impact Of Biocomponent Additive To Diesel Oil On Values Of Elected Functional Parameters Of Transport Means (Polish Journal Of Environmental Studies, V ol. 29, 2020) 
4. M. M arkiewicz, Ł. Muślewski, Survey performance and emission parameters of diesel engine powered by diesel oil and fatty acid methyl esters using fuzzy logic techniques (Fuel, Vol. 277, 2020)

5. B. Landowski, M. Baran, Analysis of selected results of engine oil tests (M A TEC W eb of Conferences 302, 01010, 2019), 18th International Conference Diagnostics of M achines and V ehicles, pp.1-7 2019),

6. B. Landowski, M. Baran, Analysis of changes in the value of selected lubricant characteristics during use (MATEC W eb of Conferences 302, 01009, 2019), 18th International Conference Diagnostics of M achines and V ehicles, pp.1-8 (2019),

7. P. A uerbach, W Kukla, Istota i zasady ekojazdy, czyli integralna część szkolenia w przedsiębiorstwach świadczacych ustugi transportowe, „Zeszyty Naukowe Politechniki Poznańskiej, Organizacja i Zarządzanie”, nr 60, (2013)

8. A. Judzińska-K łodawska, Wpływ wybranych elementów eco-drivingu na zmniejszenie zużycia paliwa oraz emisję CO2, „Autobusy”, nr 10, (2013)

9. B. Landowski, Ł. Muślewski, Numerical simulation of stochastic process as a model of technical object state changes (Engineering Mechanics 2018 Proceedings, Vol 24 Book Series: Engineering Mechanics, 24nd International Conference, may 14 - 17, 2018, Svratka, Czech Republic, B ook of full texts, Institute of Theoretical and Applied M echanics of the Czech A cademy of Sciences, Prague, pp. 485-488 (2018)

10. P. Kolber, D. Perczyński, B. Landowski, S. Wawrzyniak, The control system of the stepper motor motion with positioning accuracy verification (Engineering M echanics 2016 Proceedings, Vol 22, Book Series: Engineering Mechanics, 22nd International Conference, may 9 - 12, 2016, Svratka, Czech Republic, B ook of full texts, Institute of Thermomechanics A cademy of Sciences of the Czech Republic, pp. 298-301, 2016)

11. M. Sztal, K Wójcik, Eco driving w szkoleniu, na egzaminie, w codziennej jeździe. Wydawnictwo Grupa Image, (2015)

12. M. Pająk, L. Muślewski, B. Landowski, A. Grządziela, Fuzzy identification of the reliability state of the mine detecting ship propulsion system (Polish Maritime Research, 26 (1), pp. 55-64, 2019)

13. R. Kostek, B. Landowski, Ł. Muślewski, Simulation of rolling Bering vibration in diagnostics (J ournal of V ibroengineering, Issue 8, V olume 17, 2015)

14. B. Landowski, Ł. Muślewski, Decision model of an operation and maintenance process of city buses (Proceedings of 58th International Conference of M achine Design Departments - ICMD 2017, Publisher: Czech University of Life Sciences Prague, Czech Republic, pp. 188-193, 2017)

15. P. Kolber, D. Perczyński, K. Peszyński, B. Landowski, Efficiency testing of thermoelectric cooling cell based on peltier module. Engineering Mechanics 2018 Proceedings, Vol 24, 24nd International Conference, may 14 - 17, 2018, Svratka, Czech Republic, B ook of full texts, Institute of Theoretical and A ppiled M echanics of the Czech A cademy of Sciences, Prague, pp. 381-384 (2018)

16. A. Dykha, S. Matyukh, T. Kałaczyński, Diagnostics - Experimental Analysis of Friction Pairs at Stick - Slip Sliding, (M A TEC W eb of Conferences 302, 01009, 2019), 18th International Conference Diagnostics of M achines and V ehicles, pp.1-8 (2019),

17. A. Grządziela, J. Musiał, Ł. Muślewski, M. Pająk, A method for identification of noncoaxiality in engine shaft lines of a selected type of naval ships. (Polish Maritime Research, 1(85) V ol. 22, p 65-71, 2015)

18. Ł. Muślewski, M. Pająk, A. Grządziela, J. Musiał, Analysis of vibration time histories in the time domain for propulsion systems of minesweepers. (Journal of V ibroengineering, Issue 3, V ol. 17, p. 1309-1316, 2015) 
19. V. Martynyuk, O. Eromenko, J. Boiko, T. Kałaczyński, Diagnostics of supercapacitors, (Matec Web of Conferences) 17th International Conference Diagnostics of M achines and V ehicles, 182, 1-10, (2018)

20. M. Łukasiewicz, T. Kalaczynski, J. M usiał, J. Shalapko, Diagnostics of buggy vehicle transmission gearbox technical state based on modal vibrations (Journal of V ibroengineering Volume 16, Issue 6, Page 3137-3145, 2014) 